\title{
2-Organoselenomethyl-1H-benzimidazole Complexes of Copper(II) and Copper(I)
}

\begin{tabular}{|c|c|}
\hline Journal: & Zeitschrift für Anorganische und Allgemeine Chemie \\
\hline Manuscript ID: & zaac.200900265.R1 \\
\hline Wiley - Manuscript type: & Article \\
\hline $\begin{array}{r}\text { Date Submitted by the } \\
\text { Author: }\end{array}$ & 03-Jul-2009 \\
\hline Complete List of Authors: & $\begin{array}{l}\text { Leboschka, Markus } \\
\text { Sieger, Monika } \\
\text { Sarkar, Biprajit } \\
\text { Heck, Jürgen } \\
\text { Niemeyer, Mark } \\
\text { Bubrin, Denis } \\
\text { Lissner, Falk } \\
\text { Schleid, Thomas } \\
\text { Zalis, Stanislav } \\
\text { Su, Cheng-Yong } \\
\text { Kaim, Wolfgang; Institute of Inorganic Chemistry, Stuttgart } \\
\text { University }\end{array}$ \\
\hline Keywords: & $\begin{array}{l}\text { Coordination geometries, Copper compounds, Imidazole ligands, } \\
\text { Selenoether ligands }\end{array}$ \\
\hline
\end{tabular}

\section{scholaroNE" \\ Manuscript Central}




\section{2-Organoselenomethyl-1H-benzimidazole Complexes of Copper(II) and}

\section{Copper(I)}

Markus Leboschka, ${ }^{[a]}$ Monika Sieger, ${ }^{[a]}$ Biprajit Sarkar, ${ }^{[a]}$ Jürgen Heck, ${ }^{[a]}$ Mark

Niemeyer, ${ }^{[b]}$ Denis Bubrin, ${ }^{[a]}$ Falk Lissner, ${ }^{[a]}$ Thomas Schleid, ${ }^{[a]}$ Stanislav Zálišs, ${ }^{[c]}$ ChengYong Su, ${ }^{[d]}$ and Wolfgang Kaim ${ }^{[a], *}$

Stuttgart, Institut für Anorganische Chemie

Received

Dedicated to Professor Martin Jansen on the Occasion of his 65th Birthday

\footnotetext{
Abstract. Structurally characterized 2-methylselenomethyl- $1 H$-benzimidazole (msbi) is shown to form complexes in 2:1 ratio with copper(II). Whereas the central cation $\left[\mathrm{Cu}(\mathrm{msbi})_{2} \mathrm{Cl}\right]^{+}=\mathbf{1}^{+}$in $\left[\mathrm{Cu}(\mathrm{msbi})_{2} \mathrm{Cl}\right] \mathrm{Cl} \cdot 2 \mathrm{MeOH}$ crystallizes in an approximately mixed

* Prof. Dr. W. Kaim Fax: +4971168564165

E-mail: kaim@iac.uni-stuttgart.de

[a] Institut für Anorganische Chemie, Universität Stuttgart, Pfaffenwaldring 55, D-70550 Stuttgart, Germany

[b] Institut für Anorganische und Analytische Chemie, Universität Mainz, Duesbergweg 10-14, D-55128 Mainz, Germany

[c] J. Heyrovský Institute of Physical Chemistry, v.v.i., Academy of Sciences of the Czech Republic, Dolejškova 3, CZ-18223 Prague, Czech Republic

[d] School of Chemistry and Chemical Engineering Sun Yat-Sen University, Guangzhou, 510275, China
} 
square-pyramidal/trigonal-bipyramidal structure $(\tau=0.52)$ with the second and third row atoms $\mathrm{Cl}$ and $\mathrm{Se}$ in the equatorial plane, the related $\left[\mathrm{Cu}(\mathrm{msbi})_{2}(\mathrm{MeOH})\right]\left(\mathrm{BF}_{4}\right)_{2}=[2]\left(\mathrm{BF}_{4}\right)_{2}$ exhibits a closer to square-pyramidal arrangement with $\tau=0.36$ for that complex dication $\mathbf{2}^{2+}$. In both cases, the $\mathrm{Cu}-\mathrm{N}$ bonds are short at about $1.94 \AA$ while the $\mathrm{Cu}$-Se distances vary between $2.62 \AA$ for $\mathbf{1}^{+}$and ca. $2.54 \AA$ for $\mathbf{2}^{2+}$. Slight differences between the Jahn-Teller influenced species $\mathbf{1}^{+}$and $\mathbf{2}^{\mathbf{2 +}}$ are also apparent from absorption and EPR spectra. Since copper(I) complexes of msbi suitable for crystal structure analysis could not be obtained, the related 1-methyl-2-phenylselenomethyl- $1 H$-benzimidazole (mpsbi) was prepared and used to obtain $\left[\mathrm{Cu}(\mathrm{mpsbi})_{2}\right](\mathrm{x})=[3](\mathrm{x}), \mathrm{x}=\mathrm{BF}_{4}$ or $\mathrm{PF}_{6}$. The copper $(\mathrm{I})$ ion in the corresponding cation $3^{+}$shows a DFT-reproduced distorted tetrahedral configuration with an $\mathrm{N}-\mathrm{Cu}^{\mathrm{I}}-\mathrm{N}$ angle at $146.7(3)^{\circ}$, less straightened than the ca. $170^{\circ}$ in comparable $\mathrm{Cu}^{\mathrm{I}}$ complexes with thioether- $1 H$ benzimidazole ligands. A copper $(\mathrm{I})$ compound $\left[\mathrm{Cu}(\mathrm{psbi})_{2}\right]\left[\mathrm{Cu}(\mathrm{psbi})\left(\mathrm{psbi}-\mathrm{H}^{+}\right)\right]\left(\mathrm{PF}_{6}\right)=$ [4'](( $\left.\mathrm{PF}_{6}\right)$ with another related ligand, 2-phenylselenomethyl-1H-benzimidazole (psbi), was crystallized in partially benzimidazole-deprotonated acetonitrile solvate form, showing short $\mathrm{Cu}-\mathrm{N}$ bonds of $1.898(5) \AA$, an $\mathrm{N}-\mathrm{Cu}^{\mathrm{I}}-\mathrm{N}$ angle of $157.5(3)^{\mathrm{o}}$, a Se--Se interaction at 3.6237(3) $\AA$, and a very small Se-Cu-Se angle of $78.23(4)^{\circ}$. The different responses resulting from thioether and selenoether coordination to copper in the complexes at hand are being discussed.

Keywords: Coordination geometries; Copper compounds; Imidazole ligands; Selenoether ligands

\section{Introduction}

Organoselenium ligands are being increasingly used in coordination chemistry $[1,2]$ due to the biological function of this chalcogen $[3,4]$. Whereas the main focus has been on the important 
biological roles of the easily deprotonated selenocysteine, the "21st essential amino acid" [4], selenomethionine [5] and related selenoethers have been used as probes for NMR spectroscopic and X-ray crystallographic studies of biomolecules [5]. Following our work on copper(I) and copper(II) complexes of mixed imine-N and thioether-S chelate ligands such as 1-methyl-2-(methylthiomethyl)- $1 H$-benzimidazole (mmb) [6-8] we have now extended this approach to related imine-N/selenoether-Se ligands.<smiles>CSCc1nc2ccccc2n1C</smiles>

$\mathrm{mmb}$

The mmb and related ligands have not only allowed us to observe [9] the biochemically relevant [10] valence-tautomer equilibrium (Equation 1) outside of an enzyme [6], it also displayed a remarkable propensity to allow for facile $\mathrm{Cu}^{\mathrm{I} / \mathrm{II}}$ transitions [6-11] because of uncommon coordination geometries such as illustrated by a "see-saw" configuration [12] around the metal in $\left[\mathrm{Cu}(\mathrm{mmb})_{2}\right]^{+}$with its $2+2$ coordination arrangement (see Fig. 7 below) [6].

$$
\begin{array}{ll}
(\mathrm{L}) \mathrm{Cu}^{\mathrm{I}}\left(\mathrm{Q}^{\bullet-}\right) & (\mathrm{L}) \mathrm{Cu}^{\mathrm{II}}\left(\mathrm{Q}^{2-}\right) \\
(\text { spin on } \mathrm{Q}) & \text { (spin on copper) }
\end{array}
$$

In addition to the variation in the "minimal modeling" of certain biochemical functions, molecular copper complexes of sulfur and selenium containing ligands [2] are also of interest as potential precursor components for obtaining copper/indium/gallium/selenide or -sulfide (CIGS) photovoltaic materials $\mathrm{CuMSe}_{2}(\mathrm{M}=\mathrm{In}, \mathrm{Ga})$ [13]. 
The coordination of thioether and selenoether functions to transition metals has been reviewed and discussed with respect to the $\pi$ acceptor influence [1b,14], while recent results of methionine-rich copper(I) metalloproteins with regulatory and other functions [15] also stimulate studies in the field. Following the high-resolution protein structure analysis [16] of the monoxygenase enzyme PHM in the presence of bound $\mathrm{O}_{2}$ there have been several studies reported on mixed imidazole-thioether model ligands and their copper complexes [17].

Using the previously [8a] introduced 2-methylselenomethyl- $1 H$-benzimidazole (msbi) ligand we report here results from studies of the copper(I) and copper(II) coordination chemistry of that ligand.

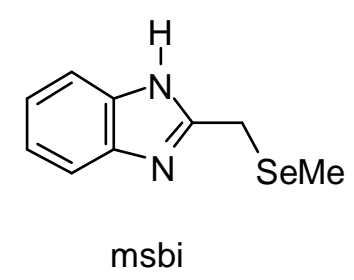

The inability to obtain a copper(I) complex of msbi suitable for crystal structure analysis prompted us to modify the 2 -selenoether- $1 H$-benzimidazole chelate system. A structurally characterized copper(I) complex of the new 1-methyl-2-phenylselenomethyl- $1 H$ benzimidazole (mpsbi) without the potential for $\mathrm{N}-\mathrm{H}$ hydrogen bonding was thus obtained and its configuration confirmed by a DFT calculation.<smiles>Cn1c(CSc2ccccc2)nc2ccccc21</smiles>

mpsbi<smiles>[SbH]c1cccnc1Cc1nc2ccccc2[nH]1</smiles>

psbi 
Another copper(I) complex ion $\left[\mathrm{Cu}(\mathrm{psbi})_{2}\right]^{+}$was obtained from the previously described [8b] ligand 2-phenylselenomethyl- $1 H$-benzimidazole $=$ psbi. Whereas the tetrafluoroborate salt could not be crystallized for structure analysis [8b], a single crystalline material was isolated in the presence of hexafluorophosphate. The structure analysis revealed a low anion content attributed to a partial deprotonation of the benzimidazole groups, a behaviour which is not uncommon in the coordination chemistry of imidazole-containing ligands $[18,19]$. The following copper compounds were studied structurally:

$\left[\mathrm{Cu}^{\mathrm{II}}(\mathrm{msbi})_{2} \mathrm{Cl}\right] \mathrm{Cl} \cdot 2 \mathrm{MeOH}=[\mathbf{1}] \mathrm{Cl} \cdot 2 \mathrm{MeOH}$

$\left[\mathrm{Cu}^{\mathrm{II}}(\mathrm{msbi})_{2}(\mathrm{MeOH})\right]\left(\mathrm{BF}_{4}\right)_{2}=[2]\left(\mathrm{BF}_{4}\right)_{2}$

$\left[\mathrm{Cu}^{\mathrm{I}}(\mathrm{mpsbi})_{2}\right]\left(\mathrm{BF}_{4}\right)=[3]\left(\mathrm{BF}_{4}\right)$

$\left[\mathrm{Cu}^{\mathrm{I}}(\mathrm{psbi})_{2}\right]\left[\mathrm{Cu}^{\mathrm{I}}(\mathrm{psbi})\left(\mathrm{psbi}-\mathrm{H}^{+}\right)\right]\left(\mathrm{PF}_{6}\right) \cdot \mathrm{CH}_{3} \mathrm{CN}=[\mathbf{4}]\left[\mathbf{4}^{\prime}\right]\left(\mathrm{PF}_{6}\right) \cdot \mathrm{CH}_{3} \mathrm{CN}$

Compounds also described are

$\left[\mathrm{Cu}^{\mathrm{I}}(\mathrm{mpsbi})_{2}\right]\left(\mathrm{PF}_{6}\right)=[3]\left(\mathrm{PF}_{6}\right)$

$\left[\mathrm{Cu}^{\mathrm{I}}(\mathrm{psbi})_{2}\right]\left(\mathrm{PF}_{6}\right)=[4]\left(\mathrm{PF}_{6}\right)$

$\left[\mathrm{Cu}^{\mathrm{I}}(\mathrm{msbi})_{2}\right]\left(\mathrm{PF}_{6}\right)=[\mathbf{5}]\left(\mathrm{PF}_{6}\right)$

\section{Results and Discussion}

\section{Ligand synthesis and structure}

The preparations of msbi and psbi via 2-chloromethyl- $1 H$-benzimidazole have been reported [8]. The mpsbi ligand was obtained similarly or by reacting $\mathrm{N}$-methyl-o-phenylenediamine with 2-phenylselenoacetic acid (see Exp. Section). 


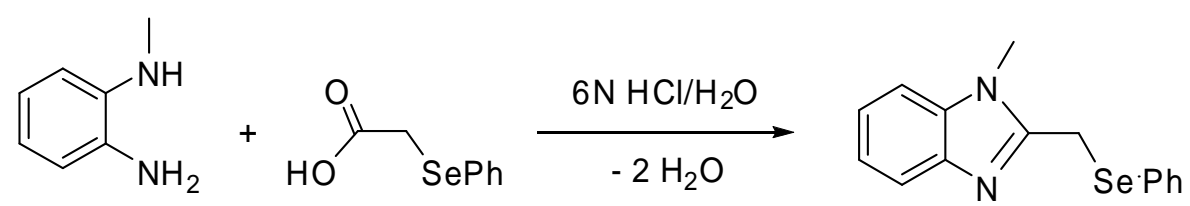

A structure determination of msbi (Table 1, Figure 1) revealed the expected non-planar conformation of the molecule in the crystal with typical bond parameters [20].

Table 1

Figure 1

\section{Copper(II) complexes of msbi}

Two different reactions of msbi with copper(II) precursors led to different crystalline materials. The reaction of msbi with $\mathrm{CuCl}_{2}$ in methanol produced crystallographically characterized $\left[\mathrm{Cu}(\mathrm{msbi})_{2} \mathrm{Cl}\right] \mathrm{Cl} \cdot 2 \mathrm{MeOH}$ (Figure 2, Tables 1,2) while the reaction with $\mathrm{Cu}\left(\mathrm{BF}_{4}\right)_{2}$ yielded $\left[\mathrm{Cu}\left(\mathrm{msbi}_{2}(\mathrm{MeOH})\right]\left(\mathrm{BF}_{4}\right)_{2}\right.$ (Figure 3, Tables 1,2).

Figures 2,3

Table 2

Structurally, both copper(II) complex ions should be affected by ligand-caused effects, i.e. by the chelate bite within the five-membered metallacycle situation and by the considerable asymmetry between the hard, basic imidazole-N and the softer, assumedly [14] $\pi$ accepting selenoether-Se donor atoms.

The main feature striking in a comparative discussion of the two complexes is a mixed trigonal-bipyramidal/square-pyramidal structure $(\tau=0.52[21])$ of the central cation $\mathbf{1}^{+}$with 
Figure 4

The observed difference in structure for both $\mathrm{Cu}^{\mathrm{II}}(\mathrm{psbi})_{2}$ structures $\mathbf{1}^{+}$and $\mathbf{2}^{\mathbf{2 +}}$ points to a sensitive situation with two strong $\mathrm{Cu}^{\mathrm{II}}-\mathrm{N}$ (imine) bonds, two weak $\mathrm{Cu}^{\mathrm{II}}-\mathrm{Se}$ (selenoether) interactions between a hard electrophile and two soft nucleophiles, and an additional donor with $\left(\mathrm{Cl}^{-}\right)$or without $(\mathrm{MeOH})$ charge. At 2.167(4) $\AA$ the $\mathrm{Cu}-\mathrm{O}$ distance for bound methanol in $\mathbf{2}^{\mathbf{2 +}}$ is relatively short [22], the $\mathrm{MeOH} \cdots \mathrm{FBF}_{3}$ hydrogen bonding at a shortest $\mathrm{O} \cdots \mathrm{F}$ distance of $2.99 \AA$ lies in a typical range [8a,23,24]. The solvate molecules in $[\mathbf{1}](\mathrm{Cl}) \cdot 2 \mathrm{MeOH}$ are connected to the non-coordinated chloride anion (Figure 2) via $\mathrm{Cl} \cdots \mathrm{HO}$ hydrogen bonds at

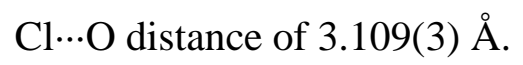

Slight differences between $\mathbf{1}^{+}$and $\mathbf{2}^{\mathbf{2 +}}$ are also apparent from absorption and ESR spectra. Overall, the spectroscopy of the copper(II) compounds did not yield unusual results. Both systems exhibit standard ESR features at $110 \mathrm{~K}$ in frozen $\mathrm{MeOH}$ with $g_{\perp}=2.063$ (partially resolved hyperfine splitting), $A_{\|}=11 \mathrm{mT}$ for ${ }^{63,65} \mathrm{Cu}$, and $g_{\|}=2.25\left(\mathbf{1}^{+}\right)$or $2.32\left(\mathbf{2}^{\mathbf{2 +}}\right)$, respectively. The absorption maxima of the weak $\left(\varepsilon=400 \mathrm{M}^{-1} \mathrm{~cm}^{-1}\right) \mathrm{d}-\mathrm{d}$ transitions lie at 760 $\mathrm{nm}\left(\mathbf{1}^{+}\right)$or $690\left(\mathbf{2}^{\mathbf{2 +}}\right)$, respectively. Both the different charges and the different structural 
configurations can account for the spectroscopic variation. Whereas $[2]\left(\mathrm{BF}_{4}\right)_{2}$ containing a labile methanol ligand shows only irreversible reduction, the chloro complex $[1] \mathrm{Cl}_{2}$ is reversibly reduced at $+0.01 \mathrm{~V}$ vs ferrocenium/ferrocene in $\mathrm{CH}_{2} \mathrm{Cl}_{2} / 0.1 \mathrm{M} \mathrm{Bu}_{4} \mathrm{NPF}_{6}$. This lower number than for the oxidation of copper(I) complexes (see below) indicates the presence of charge compensating chloride.

\section{Copper(I) compounds}

Although [5] $\left(\mathrm{PF}_{6}\right)$ could be prepared and studied spectroscopically and electrochemically (cf. below) it could not be crystallized for X-ray structure analysis. We therefore modified the $\mathrm{N}$,Se chelate ligand by methylating the $\mathrm{N} 1$ position and using $\mathrm{SePh}$ as substituent to yield mpsbi, thus preventing $\mathrm{N}-\mathrm{H}$ hydrogen bonding. Reaction of mpsbi with $\left[\mathrm{Cu}\left(\mathrm{CH}_{3} \mathrm{CN}\right)_{4}\right]\left(\mathrm{PF}_{6}\right)$ yielded $[3]\left(\mathrm{PF}_{6}\right)$, reaction with $\mathrm{Cu}\left(\mathrm{BF}_{4}\right)_{2}$ resulted in copper reduction to yield crystallizing $[3]\left(\mathrm{BF}_{4}\right)$. The reduction of copper(II) by $\mathrm{Cu}^{\mathrm{I}}$-coordinating organoelement compounds such as phosphines is not uncommon. The structural characterization of $[3]\left(\mathrm{BF}_{4}\right)$ (Figure 5, Tables 1,2) shows a $2+2$ coordination pattern [12] as for $\left[\mathrm{Cu}(\mathrm{mmb})_{2}\right]\left(\mathrm{BF}_{4}\right)$, however, with less pronounced straightening of the $\mathrm{N}-\mathrm{Cu}-\mathrm{N}$ angle at $146.7(3)^{\circ}$ vs $169.8(1)^{\circ}$ [6]. The Se system thus appoaches a more tetrahedral configuration than the related sulfur species. The remaining bond length and angle parameters are comparable with those of the $\mathrm{Cu} / \mathrm{mmb}$ system [6] and with the copper(II)/Se species described above.

Figure 5

To probe and confirm this S/Se effect we carried out DFT calculations for both species at comparable level. Table 3 shows that the agreement for the $\mathrm{Cu}$ coordination environment is good, including particularly the differences in the $\mathrm{N}-\mathrm{Cu}-\mathrm{N}$ angles. 
Table 3

Due to the larger basis set used the DFT(ADF) optimized geometry of $\left[\mathrm{Cu}(\mathrm{mmb})_{2}\right]^{+}$ describes better the experimental geometry than the previously published calculations [6]. The substantial features of the experimental structure of $\left[\mathrm{Cu}(\mathrm{mpsbi})_{2}\right]\left(\mathrm{BF}_{4}\right)$ (Table 3) are confirmed by the calculations. In particular, the calculation reproduces nicely the experimentally observed lowering of the $\mathrm{N}-\mathrm{Cu}-\mathrm{N}$ angle on going from $\left[\mathrm{Cu}(\mathrm{mmb})_{2}\right]^{+}$to the related selenoether complex.

Like for $\left[\mathrm{Cu}(\mathrm{mmb})_{2}\right]^{+}$, the highest lying molecular orbital of the selenoether complex is mainly formed by a combination of $\mathrm{d}$ orbitals from the $\mathrm{Cu}$ atom $(61 \%)$ with $\mathrm{p}$ orbitals of the chalcogen $(18 \%)$. The lowest lying unoccupied molecular orbital is composed from the $\pi^{*}$ orbital of the ligand with $11 \%$ contribution from the Se atom.

Using the psbi ligand which previously yielded single crystalline $\mathrm{Cu}^{\mathrm{II}}$ and $\mathrm{Ag}^{\mathrm{I}}$ complexes [8b] we now managed to obtain not only a $\mathrm{BF}_{4}^{-}$salt [8b] but also a hexafluorophosphate compound $\left[\mathrm{Cu}\left(\mathrm{psbi}_{2}\right]\left(\mathrm{PF}_{6}\right)\right.$ which showed a fairly high stability versus oxidation. The single crystals isolated (see Exp. Section) were found to have the composition $\left[\mathrm{Cu}^{\mathrm{I}}(\mathrm{psbi})_{2}\right]\left[\mathrm{Cu}^{\mathrm{I}}(\mathrm{psbi})\left(\mathrm{psbi}-\mathrm{H}^{+}\right)\right]\left(\mathrm{PF}_{6}\right) \cdot \mathrm{CH}_{3} \mathrm{CN} \quad$ (Figure 6, Tables 1,2). This arrangement follows from the cation/anion ratio $2 / 1$ which thus suggests a partially deprotonation of bound benzimidazole in psbi ( $3 / 4$ occupancy of $\mathrm{N}$ bound $\mathrm{H}$ ). Such deprotonations have been reported before $[18,19]$, they may be favoured by the presence of the basic heterocycles and by advantageous crystal packing (Figure 7). Supporting this concept, the (averaged) $\mathrm{Cu}-\mathrm{N}$ bond length is significantly shortened from about $1.94 \AA$ in $[\mathbf{1}]^{+},[2]^{2+}$ and $[3]^{+}$(Table 2) to $1.90 \AA$ for $[4]\left[4^{\prime}\right]^{+}$. In correspondence, the Cu-Se bond distance has increased from about 2.6 $\AA$ to $2.85 \AA$. 
Figures 6,7

An additional remarkable feature in $[4]\left[4^{\prime}\right]\left(\mathrm{PF}_{6}\right)$ is the intramolecular Se--Se interaction at 3.6237(3) $\AA$ i.e. at lower distance than the sum of the van der Waals radii of ca. $3.8 \AA[24]$. The attraction is also reflected by the enormously diminished Se-Cu-Se angle of $78.23(4)^{\circ}$ (Table 2).

The diamagnetic copper(I) compounds exhibit NMR spectra with rather small coordination induced shifts. Although $[4]\left(\mathrm{PF}_{6}\right)$ in particular is rather resistant to oxidation, the copper(I) complexes are converted eventually in air to partly Se-oxygenated products [20].

The reversible oxidation of the copper(I) compounds in $\mathrm{CH}_{2} \mathrm{Cl}_{2} / 0.1 \mathrm{M} \mathrm{Bu}_{4} \mathrm{NPF}_{6}$ occurs at $0.29 \mathrm{~V}\left([\mathbf{5}]^{+}\right), 0.38 \mathrm{~V}\left([4]^{+}\right)$and $0.39 \mathrm{~V}[3]^{+} \mathrm{vs} \mathrm{Fc}^{+/ \mathrm{o}}$, reflecting the easier oxidation for the Sealkyl instead of the Se-aryl containing system. Nevertheless, the reversibility reflects a rather small reorganization barrier between the $\mathrm{Cu}^{\mathrm{I}}$ and $\mathrm{Cu}^{\mathrm{II}}$ states [6,11], even with the selenoether donors present.

Conclusion. The metal coordination arrangements of the complex ions described here illustrate some features distinguishing selenoether from thioether complexes, viz., the diminished $\mathrm{N}-\mathrm{Cu}^{\mathrm{I}}-\mathrm{N}$ angle as a consequence of relatively stronger $\mathrm{Cu}^{\mathrm{I}}-\mathrm{Se}$ interaction and the possibility of Se--Se attraction. Remarkably, the replacement of the SR by the SeR function resulted in a less distorted-tetrahedral structure for copper(I) compounds.

The copper(II) systems are less remarkable, they show the tendency towards linear N-Cu ${ }^{\text {II }}$ $\mathrm{N}$ angles (Table 2) even if the square-pyramidal coordination is not fully achieved. Additional ligands and the flexibility of the Se donors allow for a considerable structural and spectroscopic (ESR, UV-vis) variability. Nevertheless, cyclic voltammetric measurements still exhibit reversible electron transfer $\mathrm{Cu}^{\mathrm{I}} / \mathrm{Cu}^{\mathrm{II}}$, confirming the suitability also of selenoether ligands to tolerate both oxidation states. 


\section{Experimental Section}

\section{Instrumentation}

${ }^{1}$ H-NMR spectra were taken on a Bruker AC 250 and 400 spectrometers. EPR spectra were recorded on a Bruker ESP system. UV/Vis absorption spectra were obtained using a J\&M Tidas spectrometer. Cyclic voltammetry was carried out in $0.1 \mathrm{M} \mathrm{Bu}_{4} \mathrm{NPF}_{6}$ solutions using a three-electrode configuration (glassy carbon working electrode, Pt counter electrode, $\mathrm{Ag} / \mathrm{AgCl}$ reference) and a PAR 273 potentiostat and function generator. The ferrocenium/ferrocene $\left(\mathrm{Fc}^{+} / \mathrm{Fc}\right)$ or decamethylferrocenium//decamethylferrocene couples served as internal reference.

\section{Syntheses}

\section{2-Methylselenomethyl-1H-benzimidazole (msbi)}

A solution of $0.60 \mathrm{~g}(3.2 \mathrm{mmol})$ dimethyl diselenide in $15 \mathrm{ml}$ THF is treated with an excess of $1 \mathrm{M} \mathrm{L_{BBHEt }} 3$ solution at $-10^{\circ} \mathrm{C}$. Gas evolution, discolouring and turbidity accompany the reaction. After the gas evolution has ceased $5 \mathrm{ml}$ of EtOH are added for hydrolysis of excess $\mathrm{LiBHEt}_{3}$. A suspension of $1.2 \mathrm{~g}(7.23 \mathrm{mmol})$ of 2-chloromethyl- $1 H$-benzimidazole in $15 \mathrm{ml}$ EtOH is added dropwise and then stirred overnight. After removal of solvent the yellowish ligand is purified by column chromatography on silica 60 with an ethyl acetate/petrol ether (1/1) mixture to yield $26 \%$ of the product. Anal Calc. for $\mathrm{C}_{9} \mathrm{H}_{10} \mathrm{~N}_{2} \mathrm{Se}(225.15 \mathrm{~g} / \mathrm{mol})$ : C, 47.86; H, 4.48; N, 12.44\%. Found: C, 48.01; H, 4.61; N, 12.17\%. ${ }^{1} \mathrm{H}-\mathrm{NMR}\left(\mathrm{CD}_{3} \mathrm{CN}\right): 2.04$ (s, $\left.\mathrm{CH}_{3}\right), 3.93\left(\mathrm{~s}, \mathrm{CH}_{2}\right), J\left(\mathrm{CH}^{-}{ }^{77} \mathrm{Se} 6.9 \mathrm{~Hz}\right) ; 7.15-7.25(\mathrm{~m}, \mathrm{CH}), 7.45-7.55(\mathrm{~m}, \mathrm{CH}) .{ }^{13} \mathrm{C}-\mathrm{NMR}$ $\left(\mathrm{CD}_{3} \mathrm{CN}\right): 4.8\left(\mathrm{CH}_{3}\right), 19.7\left(\mathrm{CH}_{2}\right), J\left({ }^{13} \mathrm{C}-{ }^{77} \mathrm{Se} 30 \mathrm{~Hz}\right) ; 115.7,123.2,139.3,154.6 .{ }^{77} \mathrm{Se}-\mathrm{NMR}$ $\left(\mathrm{CD}_{3} \mathrm{CN}\right): 155$. 


\section{1-Methyl-2-phenylselenomethyl-1H-benzimidazole (mpsbi)}

A mixture of $0.73 \mathrm{~g}(6.0 \mathrm{mmol})$ freshly distilled $\mathrm{N}$-methyl- $o$-phenylenediamine and $1.31 \mathrm{~g}$ (6.1 mmol) of 2-phenylselenoacetic acid was heated to reflux for $20 \mathrm{~h}$ in $25 \mathrm{ml}$ of half concentrated hydrochloric acid. After removal of the excess hydrochloric acid under vacuum the residue was suspended in $25 \mathrm{ml} \mathrm{H}_{2} \mathrm{O}$ and added slowly to $25 \mathrm{ml}$ of cold concentrated ammonia solution. The dark oil formed was extracted several times with dichloromethane. Drying with $\mathrm{Na}_{2} \mathrm{SO}_{4}$ and removal of $\mathrm{CH}_{2} \mathrm{Cl}_{2}$ yielded a brown solid which was dissolved in ethyl acetate. After filtering the solution and adding a few drops of triethylamine the mixture was chromatographed on a silica column (ethyl acetate/petrol ether 80/20) to yield a light brown oil which solidified at $0^{\circ} \mathrm{C}$. Recrystallization from ethyl acetate yielded the light brownish product in $47 \%$ yield $(0.84 \mathrm{~g})$. Anal Calc. for $\mathrm{C}_{15} \mathrm{H}_{14} \mathrm{~N}_{2} \mathrm{Se}(301.24 \mathrm{~g} / \mathrm{mol})$ : C, 59.81 ; H, 4.68; N, 9.30\%. Found: C, 59.90; H, 4.72; N, 9.25\%. ${ }^{1} \mathrm{H}-\mathrm{NMR}\left(\mathrm{CDCl}_{3}\right): 3.56\left(\mathrm{~s}, \mathrm{CH}_{3}\right)$, $4.31\left(\mathrm{~s}, \mathrm{CH}_{2}\right), 7.15-7.70(\mathrm{~m}, \mathrm{CH}) .{ }^{13} \mathrm{C}-\mathrm{NMR}\left(\mathrm{CDCl}_{3}\right): 22.6\left(\mathrm{CH}_{2}\right), 30.5\left(\mathrm{CH}_{3}\right), 109.5,119.9$, 122.6, 123.1, 128.5, 129.6, 134.5, 134.6, 136.0, 143.3, 150.5. ${ }^{77} \mathrm{Se}-\mathrm{NMR}\left(\mathrm{CDCl}_{3}\right)$ : 937. The compound was alternatively obtained by reacting the corresponding 1-methyl-2chloromethyl-1H-benzimidazole with $\mathrm{PhSe}^{-}[8 \mathrm{~b}]$.

\section{$\left[\mathrm{Cu}(\mathrm{msbi})_{2} \mathrm{Cl}\right] \mathrm{Cl} \cdot 2 \mathrm{MeOH}=[1](\mathrm{Cl}) \cdot 2 \mathrm{MeOH}$}

$100 \mathrm{mg}(0.44 \mathrm{mmol})$ of msbi and $30 \mathrm{mg}(0.22 \mathrm{mmol})$ of $\mathrm{CuCl}_{2}$ were dissolved in $10 \mathrm{ml}$ $\mathrm{CH}_{3} \mathrm{OH}$ by gentle heating. Slow cooling yielded greenish crystals in $87 \%$ yield $(112 \mathrm{mg})$. Anal Calc. for $\mathrm{C}_{20} \mathrm{H}_{28} \mathrm{Cl}_{2} \mathrm{CuN}_{4} \mathrm{O}_{2} \mathrm{Se}_{2}(648.82 \mathrm{~g} / \mathrm{mol})$ : C, 37.02; H, 4.13; N, 8.64\%. Found: C, $36.10 ; \mathrm{H}, 4.35 ; \mathrm{N}, 8.73 \%$.

$\left[\mathrm{Cu}(\mathrm{msbi})_{2}(\mathrm{MeOH})\right]\left(\mathrm{BF}_{4}\right)_{2}=[2]\left(\mathrm{BF}_{4}\right)_{2}$ 
$100 \mathrm{mg}(0.44 \mathrm{mmol})$ of msbi and $52 \mathrm{mg}(0.22 \mathrm{mmol})$ of $\mathrm{Cu}\left(\mathrm{BF}_{4}\right)_{2}$ were dissolved in $2 \mathrm{ml}$ $\mathrm{CH}_{3} \mathrm{OH}$. Layering with $10 \mathrm{ml}$ diethyl ether and cooling to $-18^{\circ} \mathrm{C}$ yielded green crystals in $35 \%$ yield (56 mg). Anal Calc. for $\mathrm{C}_{19} \mathrm{H}_{24} \mathrm{~B}_{2} \mathrm{CuF}_{8} \mathrm{~N}_{4} \mathrm{OSe}_{2}(719.50 \mathrm{~g} / \mathrm{mol})$ : C, 31.72; $\mathrm{H}, 3.36$; $\mathrm{N}$, 7.79\%. Found: C, 31.45; H, 3.62; N, 7.60\%.

\section{$\left[\mathrm{Cu}(\mathrm{mpsbi})_{2}\right]\left(\mathrm{PF}_{6}\right)=[3]\left(P F_{6}\right)$}

The precursor compound $\left[\mathrm{Cu}\left(\mathrm{CH}_{3} \mathrm{CN}\right)_{4}\right]\left(\mathrm{PF}_{6}\right)(50 \mathrm{mg}, 0.134 \mathrm{mmol})$ and the ligand mpsbi $(81$ $\mathrm{mg}, 0.268 \mathrm{mmol}$ ) were mixed under argon in $10 \mathrm{ml} \mathrm{CH} \mathrm{CH}_{3} \mathrm{CN}$, stirred for 2 hours, and the solvent was slowly removed to yield $72 \mathrm{mg}(66 \%)$ of the sensitive product. Anal Calc. for $\mathrm{C}_{30} \mathrm{H}_{28} \mathrm{CuF}_{6} \mathrm{~N}_{4} \mathrm{PSe}_{2}$ (811.01 g/mol): C, 44.43; H, 3.48; N, 6.91\%. Found: C, 43.94; H, 3.25; N, 7.05\%. ${ }^{1} \mathrm{H}-\mathrm{NMR}\left(\mathrm{CD}_{3} \mathrm{CN}\right): 3.73\left(\mathrm{~s}, \mathrm{CH}_{3}\right), 4.42\left(\mathrm{~s}, \mathrm{CH}_{2}\right), J\left(\mathrm{CH}_{2^{-}}{ }^{77} \mathrm{Se} 6.9 \mathrm{~Hz}\right) ; 7.14-7.58(\mathrm{~m}$, $\mathrm{CH}) .{ }^{13} \mathrm{C}-\mathrm{NMR}\left(\mathrm{CD}_{3} \mathrm{CN}\right): 23.4\left(\mathrm{CH}_{2}\right), J\left({ }^{13} \mathrm{C}-{ }^{77} \mathrm{Se} 30 \mathrm{~Hz}\right) ; 30.5\left(\mathrm{CH}_{3}\right), 110.7,118.1,123.1$, $123.6,128.2,128.6,129.2,129.4,129.6,135.9,155.2 .{ }^{77} \mathrm{Se}-\mathrm{NMR}\left(\mathrm{CD}_{3} \mathrm{CN}\right): 309$.

$\left[\mathrm{Cu}\left(\mathrm{msbi}_{2}\right]\left(P F_{6}\right)=[5]\left(P F_{6}\right)\right.$

The precursor $\left[\mathrm{Cu}\left(\mathrm{CH}_{3} \mathrm{CN}\right)_{4}\right]\left(\mathrm{PF}_{6}\right)(50 \mathrm{mg}, 0.134 \mathrm{mmol})$ and the ligand $\mathrm{msbi}(60 \mathrm{mg}, 0.268$ mmol) were stirred in $10 \mathrm{ml} \mathrm{CH}_{3} \mathrm{CN}$ for 2 hours, and the solvent was slowly removed to yield $68 \mathrm{mg}(72 \%)$ of the very sensitive product. Anal Calc. for $\mathrm{C}_{18} \mathrm{H}_{20} \mathrm{CuF}_{6} \mathrm{~N}_{4} \mathrm{PSe}_{2}(658.81 \mathrm{~g} / \mathrm{mol})$ : C, 32.82; H, 3.06; N, 8.51\%. Found: C, 32.78; H, 2.97; N, 9.10\%. ${ }^{1} \mathrm{H}-\mathrm{NMR}\left(\mathrm{CD}_{3} \mathrm{CN}\right): 2.11$ (s, $\left.\mathrm{CH}_{3}\right), 4.05\left(\mathrm{~s}, \mathrm{CH}_{2}\right) ; 7.28-7.62(\mathrm{~m}, \mathrm{CH}) .{ }^{13} \mathrm{C}-\mathrm{NMR}\left(\mathrm{CD}_{3} \mathrm{CN}\right): 6.3\left(\mathrm{CH}_{3}\right), 21.3\left(\mathrm{CH}_{2}\right), 30.5$ $\left(\mathrm{CH}_{3}\right), 115.1,123.1,129.7,154.8$.

\section{$\left[\mathrm{Cu}\left(\mathrm{mpsbi}_{2}\right)_{2}\right]\left(\mathrm{BF}_{4}\right)=[3]\left(\mathrm{BF}_{4}\right)$}

A solution of $83 \mathrm{mg}(0.28 \mathrm{mmol})$ of mpsbi in $3 \mathrm{ml} \mathrm{MeOH}$ was treated with a solution of 48 $\mathrm{mg}(0.14 \mathrm{mmol})$ of $\mathrm{Cu}\left(\mathrm{BF}_{4}\right)_{2} \cdot 6 \mathrm{H}_{2} \mathrm{O}$ in $3 \mathrm{ml}$ methanol. The dark-green solution was stirred for one day, the solvent volume reduced to $50 \%$ and a green solid precipitated by cooling to $4^{\circ} \mathrm{C}$. 
Redissolving in dry $\mathrm{MeOH}$ and keeping at $4^{\circ} \mathrm{C}$ produced $12 \mathrm{mg}(11 \%)$ of colorless crystals (rods) suitable for X-ray diffraction. ${ }^{1} \mathrm{H}-\mathrm{NMR}\left(\mathrm{CDCl}_{3}\right)$ : $3.71\left(\mathrm{~s}, \mathrm{CH}_{3}\right), 4.45\left(\mathrm{~s}, \mathrm{CH}_{2}\right), 7.15$ $7.70(\mathrm{~m}, \mathrm{CH})$.

$\left[\mathrm{Cu}(\mathrm{psbi})_{2}\right]\left(P F_{6}\right)=[4]\left(P F_{6}\right)$

The precursor compound $\left[\mathrm{Cu}\left(\mathrm{CH}_{3} \mathrm{CN}\right)_{4}\right]\left(\mathrm{PF}_{6}\right)(50 \mathrm{mg}, 0.134 \mathrm{mmol})$ and the ligand psbi (77 $\mathrm{mg}, 0.268 \mathrm{mmol}$ ) were mixed under argon in $10 \mathrm{ml} \mathrm{CH}_{3} \mathrm{CN}$, stirred for 2 hours, and the solvent was slowly removed to yield $87 \mathrm{mg}(83 \%)$ of the product. Anal Calc. for $\mathrm{C}_{28} \mathrm{H}_{24} \mathrm{CuF}_{6} \mathrm{~N}_{4} \mathrm{PSe}_{2}$ (782.95 g/mol): C, 42.95; H, 3.09; N, 7.16\%. Found: C, 42.56; H, 3.45; N, 6.86\%. ${ }^{1} \mathrm{H}-\mathrm{NMR}\left(\mathrm{CD}_{3} \mathrm{CN}\right): 4.39\left(\mathrm{~s}, \mathrm{CH}_{2}\right), 7.18-7.60(\mathrm{~m}, \mathrm{CH}) \cdot{ }^{13} \mathrm{C}-\mathrm{NMR}\left(\mathrm{CD}_{3} \mathrm{CN}\right): 26.0$, $117.8,124.4,129.0,129.6,130.0,133.5,163.5,186.0$. Crystallization at $-18^{\circ} \mathrm{C}$ of an acetonitrile solution produced single crystals of $\left[\mathrm{Cu}^{\mathrm{I}}(\mathrm{psbi})_{2}\right]\left[\mathrm{Cu}(\mathrm{psbi})\left(\mathrm{psbi}-\mathrm{H}^{+}\right)\right]\left(\mathrm{PF}_{6}\right) \cdot \mathrm{CH}_{3} \mathrm{CN}$ $=[4]\left[4^{\prime}\right]\left(\mathrm{PF}_{6}\right) \cdot \mathrm{CH}_{3} \mathrm{CN}$. Anal. Calc. for $\mathrm{C}_{58} \mathrm{H}_{50} \mathrm{Cu}_{2} \mathrm{~F}_{6} \mathrm{~N}_{9} \mathrm{PSe}_{4}(1462.901 \mathrm{~g} / \mathrm{mol}): \mathrm{C}, 47.68 ; \mathrm{H}$, 3.45; N, 8.63\%. Found: C, 47.58; H. 3.54; N, 8.66\%.

\section{Crystal Structure Determination}

Colorless single crystals of $[3]\left(\mathrm{BF}_{4}\right)$ were obtained from a methanol solution at $4{ }^{\circ} \mathrm{C}$. Green single crystals of $[2]\left(\mathrm{BF}_{4}\right)_{2}$ were grown by slow diffusion of diethyl ether into a methanol solution. Data for both crystals were collected at $293 \mathrm{~K}$ with a NONIUS Kappa CCD diffractometer. Green single crystals of $[\mathbf{1}] \mathrm{Cl} \cdot 2 \mathrm{MeOH}$ were obtained by slow evaporation from a saturated methanol solution, single crystals of [4][4'] $\left(\mathrm{PF}_{6}\right) \cdot \mathrm{CH}_{3} \mathrm{CN}$ were obtained from a concentrated acetonitrile solution, and single crystals of msbi were grown from an ethyl acetate/petrol ether (1/1) mixture by slow evaporation at room temperature. Data collection for these crystals was performed at $173 \mathrm{~K}\left(\mathrm{msbi},[4]\left[\mathbf{4}^{\prime}\right]\left(\mathrm{PF}_{6}\right) \cdot \mathrm{CH}_{3} \mathrm{CN}\right)$ and $293 \mathrm{~K}([1] \mathrm{Cl} \cdot 2 \mathrm{MeOH})$ on a Siemens P4 diffractometer employing the $\omega-2 \theta$ scan technique. 


\section{DFT Calculations}

Ground state electronic structure calculations of the complex ions $\left[\mathrm{Cu}(\mathrm{mmb})_{2}\right]^{+}$and $\left[\mathrm{Cu}(\mathrm{mpsbi})_{2}\right]^{+}$have been done by the density-functional theory (DFT) method using ADF2007.1 [26-28]. Slater type orbital (STO) basis sets of triple- $\zeta$ quality with two polarization functions for $\mathrm{S}, \mathrm{Se}$ and $\mathrm{Cu}$ and triple- $\zeta$ quality with one polarization function for the other atoms were employed. The inner shells were represented by the frozen core approximation (1s for $\mathrm{C}, \mathrm{N}, 2 \mathrm{p}$ for $\mathrm{S}, 3 \mathrm{p}$ for $\mathrm{Se}$ and $1 \mathrm{~s}-2 \mathrm{p}$ for $\mathrm{Cu}$ were kept frozen). The following density functionals were used within ADF: The local density approximation (LDA) with VWN parametrization of electron gas data or the functional including Becke's gradient correction [29] to the local exchange expression in conjunction with Perdew's gradient correction [30] to the LDA expression (ADF/BP). The scalar relativistic (SR) zero order regular approximation (ZORA) was used within this study. Geometry optimizations were done without any symmetry constraints. 
This work was supported by the Deutsche Forschungsgemeinschaft (SFB 706), the Fonds der Chemischen Industrie, the EU (COST D35), the Grant Agency of the Academy of Sciences of the Czech Republic (KAN 100400702) and the Ministry of Education of the Czech Republic (Grant COST OC 139). 


\section{References}

[1] (a) A. Panda, S. C. Menon, H. B. Singh, C. P. Morley, R Bachman, T M. Cocker, R. J. Butcher, Eur. J. Inorg. Chem. 2005, 1114; (b) S. G. Murray, F. R. Hartley, Chem. Rev. 1981, 81,365

[2] (a) S. Dey, L. B. Kumbhare, V. K. Jain, T. Schurr, W. Kaim, A. Klein, F. Belaj, Eur. J. Inorg. Chem. 2004, 4510; (b) S. Dey, V. K. Jain, A. Knödler, A. Klein, W. Kaim, S. Zalis, Inorg. Chem. 2002, 41, 2864; (c) S. Dey, V. K. Jain, S. Chaudhury, A. Knoedler, F. Lissner, W. Kaim, J. Chem. Soc., Dalton Trans. 2001, 723.

[3] (a) C. Jacob, G. I. Giles, N. M. Giles, H. Sies, Angew. Chem. 2003, 115, 4890; Angew. Chem. Int. Ed. 2003, 42, 4742; (b) W.-W. du Mont, G. Mugesh, C. Wismach, P. G. Jones, Angew. Chem. 2001, 113, 2547; Angew. Chem. Int. Ed. 2001, 40, 2486; (c)

[4] H. Engelberg-Kulka, R. Schoulaker-Schwarz, Trends Biochem. Sci. 1988, 13, 419.

[5] (a) G. Roelfes, D. Hilvert, Angew. Chem. 2003, 115, 2377; Angew. Chem. Int Ed. 2003, 42, 2275; (b) G. N. Schrauzer, Adv. Food Nutr. Res. 2003, 47, 73; (c) S. M. Berry, M. Ralle, D. W. Low, N. J. Blackburn, Y. Lu, J. Am. Chem. Soc. 2003, 125, 8760.

[6] M. Albrecht, K. Hübler, S. Zalis, W. Kaim, Inorg. Chem. 2000, 39, 4731.

[7] (a) J. Rall, E. Waldhör, B. Schwederski, M. Schwach, S. Kohlmann, W. Kaim, in Bioinorganic Chemistry: Transition Metals in Biology and their Coordination Chemistry, (A. X. Trautwein, Ed.), VCH, Weinheim (Germany), 1997, p 476; (b) M. Albrecht, K. Hübler, T. Scheiring, W. Kaim, Inorg. Chim. Acta 1999, 287, 204; (c) W. Kaim, M. Wanner, A. Knödler, S. Zalis, Inorg. Chim. Acta 2002, 337, 163.

[8] (a) M. Leboschka, M. Sieger, M. Niemeyer, S. Záliš, W. Kaim, Z. Anorg. Allg. Chem. 2008, 634, 2343; (b) M. Leboschka, M. Sieger, B. Sarkar, M. Niemeyer, T. Schurr, J. Fiedler, S. Záliš, W. Kaim, Z. Anorg. Allg. Chem. 2009, 635, 1001.

[9] J. Rall, M. Wanner, M. Albrecht, F. M. Hornung, W. Kaim, Chem. Eur. J. 1999, 5, 2802. 
[10] (a) M. Mure, Acc. Chem. Res. 2004, 37, 131; (b) R. Medda, A. Padiglia, A. Bellelli, J. Z. Pedersen, A. Finazzi Agro, G. Floris, FEBS Lett. 1999, 453, 1; (c) R. Medda, A. Mura, S. Longu, R. Anedda, A. Padiglia, M. Casu, G. Floris, Biochimie 2006, 88, 827.

[11] (a) D. B. Rorabacher, Chem. Rev. 2004, 104, 651; (b) S. Torelli, C. Belle, C. Philouze, J.-L. Pierre, W. Rammal, E. Saint-Aman, Eur. J. Inorg. Chem. 2003, 2452.

[12] (a) S. Alvarez, P. Alemany, D. Casanova, J. Cirera, M. Llunell, D. Avnir, Coord. Chem. Rev. 2005, 249, 1693; (b) I. Persson, K. B. Nilsson, Inorg. Chem. 2006, 45, 7428; (c) S. Ekici, M. Nieger, R. Glaum, E. Niecke, Angew. Chem. 2003, 115, 451; Angew. Chem. Int. Ed. 2003, 42, 435.

[13] (a) M. Afzaal, D. J. Crouch, P. O'Brien, J. Raftery, P. J. Skabara, A. J. P. White, D. J. Williams, J. Mater. Chem. 2004, 14, 233. (b) D. L. Castro, S. G. Bailey, R. P. Rafaelle, K. K. Banger, A. F. Hepp, Chem. Mater. 2003, 15, 3142. (c) J. J. Vittal, M. T. Ng, Acc. Chem. Res. 2006, 39, 869.

[14] (a) H.-B. Kraatz, H. Jacobsen, T. Ziegler. P. M. Boorman, Organometallics 1993, 12, 76; (b) W. Kaim, J. Biol. Inorg. Chem. 2007, 12 (Suppl I) (2007) S121.

[15] (a) A. V. Davis, T. O'Halloran, Nature Chem. Biol. 2008, 4, 148; (b) C. Belle, W. Rammal, J.-L. Pierre, J. Inorg. Biochem. 2005, 99, 1929.

[16] S. T. Prigge, B. A. Eipper, R. E. Mains, L. M. Amzel, Science 2004, 304, 864.

[17] (a) L. Zhou, D. Powell, K. M. Nicholas, Inorg. Chem. 2006, 45, 3840; (b) L. Q. Hatcher, D.-H. Lee, M. A. Vance, A. E. Milligan, R. Sarangi, K. O. Hodgson, B. Hedman, E. I. Solomon, K. D. Karlin, Inorg. Chem. 2006, 45, 10055; (c) N. W. Aboelella, B. F. Gherman, L. M. R. Hill, J. T. York, N. Holm, V. G. Young, Jr., C. J. Cramer, W. B. Tolman, J. Am. Chem. Soc. 2006, 128, 3445.

[18] C.-L. Chen, Q. Zhang, J.-H. Yao, J.-Y. Zhang, B.-S. Kang, C.-Y. Su, Inorg. Chim. Acta 2008, 361, 2934. 
[19] (a) C.-Y. Su, A. M. Goforth, M. D. Smith, P. J. Pellechia, H.-C. zur Loye, J. Am. Chem. Soc. 2004, 126, 3576; (b) C.-L. Chen, H.-Y. Tan, J.-H. Yao, Y.-Q. Wan, C.-Y. Su, Inorg. Chem. 2005, 44, 8510; (c) X.-L. Zhang, S.-R. Zheng, Y.-R. Liu, X.-L. Zheng, C.Y. Su, Acta Cryst. 2005, C61, 533; (d) S.-R. Zheng, Y.-P. Cai, X.-L. Zhang, C.-Y. Su, Acta Cryst. 2005, C61, 642.

[20] M. Leboschka, Ph.D. Thesis, University of Stuttgart, 2009.

[21] (a) A. W. Addison, T. N. Rao, J. Reedijk, J. van Rijn, G. C. Verschoor, J. Chem.Soc., Dalton Trans. 1984, 1349; (b) A. Schmuck, K. Seppelt, Chem. Ber. 1989, 122, 803.

[22] G. van Albada, W. Smeets, A. Spek, J. Reedijk, J. Chem. Cryst. 1998, 28, 427; (b) O. Nobuo, M. Yasunori, O. Mamiko, Acta Cryst. 2004, C60, 345.

[23] R. W. M. Ten Hoedt, W. L. Driessen, G. C. Verschoor, Acta Cryst. 1983, C39, 71.

[24] J. E. Huheey, E. A. Keiter, R. L. Keiter, Inorganic Chemistry, 4th ed., Harper Collins, New York, 1993, p 292.

[25] (a) G. M. Sheldrick, Program for Crystal Structure Solution and Refinement, Universität Göttingen, 1997; (b) G. M. Sheldrick, SHELXTL, version 5.10; Bruker AXS Inc., Madison, Wisconsin, 1998.

[26] (a) G. te Velde, F. M. Bickelhaupt, S. J. A. van Gisbergen, C. Fonseca Guerra, E. J. Baerends, J. G. Snijders, T. Ziegler, J. Comput. Chem. 2001, 22, 931; (b) ADF2007.01, SCM, Theoretical Chemistry, Vrije Universiteit, Amsterdam, The Netherlands, http://www.scm.com

[27] C. Fonseca Guerra, J. G. Snijders, G. te Velde, E. J. Baerends, Theor. Chem. Acc. 1998, $99,391$.

[28] S. J. A. van Gisbergen, J. G. Snijders, E. J. Baerends, Comput. Phys. Commun. 1999, $118,119$.

[29] A. D. Becke, Phys. Rev. A 1988, 38, 3098.

[30] J. P. Perdew, Phys. Rev. A 1986, 33, 8822. 
Table 1. Crystal and refinement data for ligand and complexes

\begin{tabular}{|c|c|c|c|c|c|}
\hline & msbi & {$[1](\mathrm{Cl}) \cdot 2 \mathrm{MeOH}$} & {$[2]\left(\mathrm{BF}_{4}\right)_{2}$} & {$[3]\left(\mathrm{BF}_{4}\right)$} & {$[4]\left[4^{\prime}\right]\left(\mathrm{PF}_{6}\right) \cdot \mathrm{CH}_{3} \mathrm{CN}$} \\
\hline empirical formula & $\mathrm{C}_{9} \mathrm{H}_{10} \mathrm{~N}_{2} \mathrm{Se}$ & $\mathrm{C}_{20} \mathrm{H}_{28} \mathrm{Cl}_{2} \mathrm{CuN}_{4} \mathrm{O}_{2} \mathrm{Se}_{2}$ & $\mathrm{C}_{19} \mathrm{H}_{24} \mathrm{~B}_{2} \mathrm{CuF}_{8} \mathrm{~N}_{4} \mathrm{OSe}_{2}$ & $\mathrm{C}_{30} \mathrm{H}_{28} \mathrm{BCuF}_{4} \mathrm{~N}_{4} \mathrm{Se}_{2}$ & $\mathrm{C}_{58} \mathrm{H}_{50} \mathrm{Cu}_{2} \mathrm{~F}_{6} \mathrm{~N}_{9} \mathrm{PSe}_{4}$ \\
\hline molar mass & 225.15 & 648.82 & 719.52 & 752.83 & 1460.96 \\
\hline temperature $(\mathrm{K})$ & $173(2)$ & 293(2) & 293(2) & 293(2) K & $173(2) \mathrm{K}$ \\
\hline wavelength $(\AA)$ & 0.71073 & 0.71073 & 0.71073 & 0.71073 & 0.71073 \\
\hline crystal system & orthorhombic & monoclinic & monoclinic & monoclinic & tetragonal \\
\hline space group & $P b c a$ & $C 2 / c$ & $C 2 / c$ & $C 2 / m$ & $P 4 / n$ \\
\hline \multirow[t]{4}{*}{ cell dimensions $(\AA)$} & $a=8.7058(9)$ & $a=17.516(4)$ & $a=21.4292(5)$ & $a=20.6470(7)$ & $a=13.6880(19)$ \\
\hline & $b=9.7525(11)$ & $b=11.667(2)$ & $b=17.6223(4)$ & $b=6.5126(3)$ & $b=13.6880(19)$ \\
\hline & $c=21.747(2)$ & $c=12.566(3)$ & $c=16.4925(4)$ & $c=12.6499(6)$ & $c=15.174(3)$ \\
\hline & & $\beta=105.75(3)^{\circ}$ & $\beta=121.096(1)^{\circ}$ & $\beta=116.030(2)^{\circ}$ & \\
\hline cell volume $\left(\AA^{3}\right)$ & $1846.4(3)$ & 2471.6(9) & $5333.1(2)$ & $1528.44(11)$ & $2843.0(8)$ \\
\hline $\mathrm{Z}$ & 8 & 4 & 8 & 2 & 2 \\
\hline calc. density $\left(\mathrm{Mg} / \mathrm{m}^{3}\right)$ & 1.620 & 1.744 & 1.737 & 1.636 & 1.707 \\
\hline absorption coefficient $\left(\mathrm{mm}^{-1}\right)$ & 4.012 & 4.070 & 3.625 & 3.147 & 3.404 \\
\hline
\end{tabular}




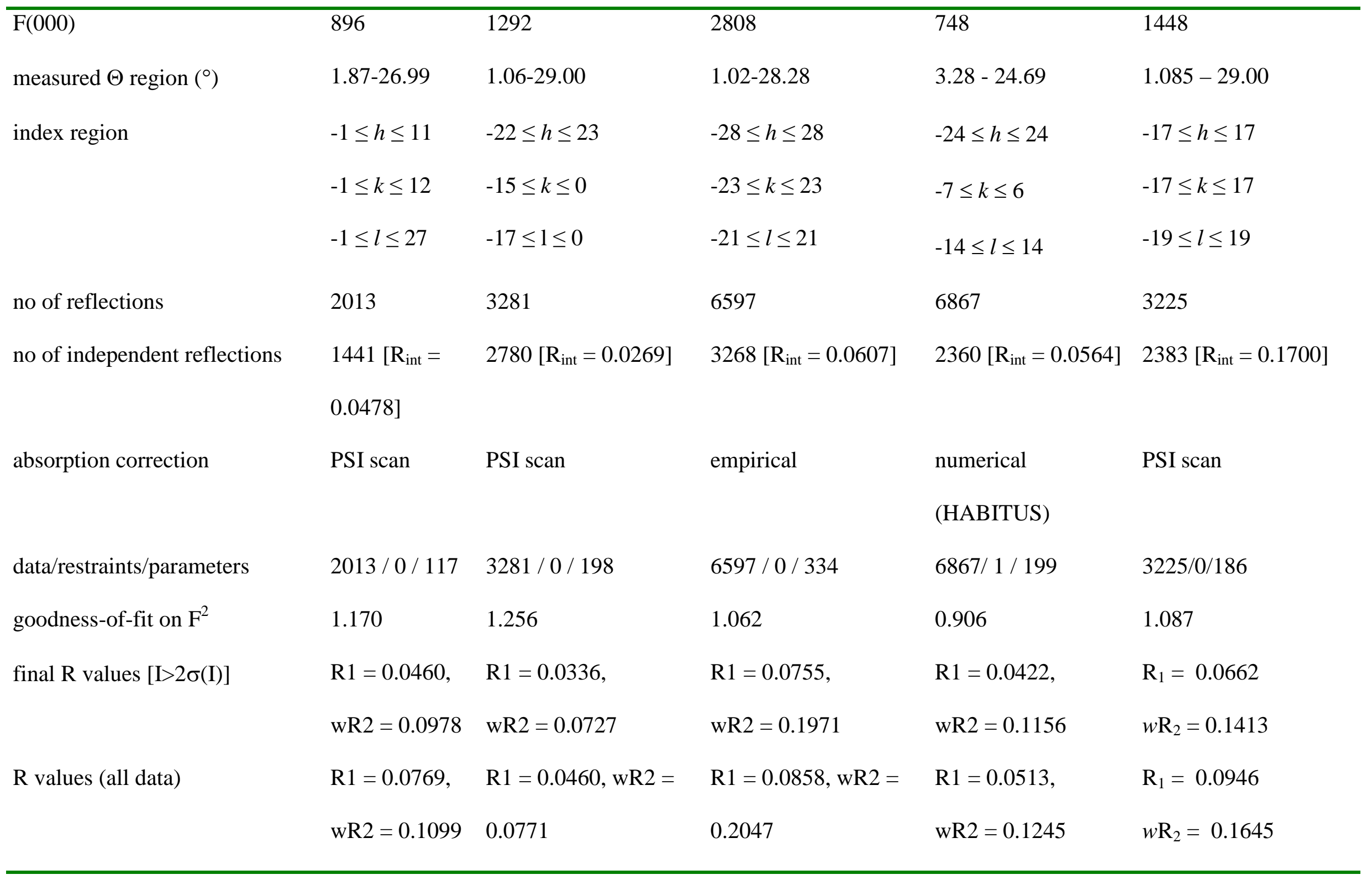


Table 2 Selected bond parameters

\begin{tabular}{llllll}
\hline compound & $\mathrm{Cu}-\mathrm{N}$ & $\mathrm{Cu}-\mathrm{Se}$ & $\mathrm{N}-\mathrm{Cu}-\mathrm{N}$ & $\mathrm{Se}-\mathrm{Cu}-\mathrm{Se}$ & $\mathrm{Se}-\mathrm{Cu}-\mathrm{N}$ \\
\hline$[\mathbf{1}] \mathrm{Cl} \cdot 2 \mathrm{MeOH}$ & $1.944(2)$ & $2.6205(6)$ & $169.17(12)$ & $133.75(2)$ & $82.60(6) ; 93.13(6)$ \\
{$[\mathbf{2}]\left(\mathrm{BF}_{4}\right)_{2}$} & $1.933(5)$ & $2.532(1)$ & $171.2(2)$ & $150.60(4)$ & $83.4(2) ; 94.8(2)$ \\
& $1.947(5)$ & $2.552(1)$ & & & $82.7(2) ; 95.1(2)$ \\
& $1.948(5)$ & $2.632(1)$ & $146.7(3)$ & $110.91(6)$ & $84.1(2) ; 115.4(2)$ \\
{$[3]\left(\mathrm{BF}_{4}\right)$} & $1.898(5)$ & $2.849(1)$ & $157.5(3)$ & $78.23(4)$ & $81.9(2) ; 116.4(2)$ \\
{$\left[\mathbf{4}^{\prime}\right]\left(\mathrm{PF}_{6}\right) \cdot \mathrm{CH}_{3} \mathrm{CN}$} & & & & \\
\hline
\end{tabular}


Table 3. Comparison of Selected Experimental and Calculated Bond Lengths $[\AA]$ and Angles $\left.{ }^{\circ}\right]$ within $\left[\mathrm{Cu}(\mathrm{mpsbi})_{2}\right]\left(\mathrm{BF}_{4}\right)$ and $\left[\mathrm{Cu}\left(\mathrm{mmb}_{2}\right]\left(\mathrm{BF}_{4}\right)\right.$.

\begin{tabular}{|c|c|c|c|c|}
\hline \multirow[b]{2}{*}{ Bond length } & \multicolumn{2}{|c|}{$\mathrm{X}=\mathrm{Se}(\mathrm{L}=\mathrm{mpsbi})$} & \multicolumn{2}{|c|}{$\mathrm{X}=\mathrm{S}(\mathrm{L}=\mathrm{mmb})$} \\
\hline & $\begin{array}{l}\text { exp. } \\
\text { (this work) }\end{array}$ & $\begin{array}{l}\text { calc. } \\
\text { (this work) }\end{array}$ & $\begin{array}{l}\text { exp. } \\
{[6]}\end{array}$ & $\begin{array}{l}\text { calc. } \\
\text { (this work) }\end{array}$ \\
\hline $\mathrm{Cu}-\mathrm{N}(1)$ & $1.948(5)$ & 1.928 & $1.9199(18)$ & 1.918 \\
\hline $\mathrm{Cu}-\mathrm{X}$ & $2.632(1)$ & 2.636 & $2.6216(7)$ & 2.702 \\
\hline $\mathrm{X}-\mathrm{C}(9)$ & $1.925(4)$ & 1.982 & $1.801(3)$ & 1.824 \\
\hline $\mathrm{X}-\mathrm{C}(10)$ & $1.914(5)$ & 1.947 & $1.806(3)$ & 1.826 \\
\hline \multicolumn{5}{|l|}{ Bond angle } \\
\hline $\mathrm{N}(1) \# 1-\mathrm{Cu}-\mathrm{N}(1)$ & $146.7(3)$ & 146.3 & $169.75(11)$ & 166.6 \\
\hline $\mathrm{N}(1) \# 1-\mathrm{Cu}-\mathrm{X}$ & $115.35(15)$ & 114.0 & $103.56(6)$ & 106.9 \\
\hline $\mathrm{N}(1)-\mathrm{Cu}-\mathrm{X}$ & $84.09(15)$ & 86.0 & $82.47(6)$ & 81.8 \\
\hline $\mathrm{X}-\mathrm{Cu}-\mathrm{X} \# 1$ & $110.91(6)$ & 109.1 & $109.33(3)$ & 112.2 \\
\hline $\mathrm{C}(9)-\mathrm{X}-\mathrm{Cu}$ & $90.47(12)$ & 88.4 & $90.42(9)$ & 89.7 \\
\hline $\mathrm{C}(10)-\mathrm{X}-\mathrm{Cu}$ & $93.98(13)$ & 96.1 & $93.7(1)$ & 93.2 \\
\hline $\mathrm{C}(10)-\mathrm{X}-\mathrm{C}(9)$ & 101.1(2) & 100.3 & $100.7(1)$ & 101.1 \\
\hline $\mathrm{C}(8)-\mathrm{N}(1)-\mathrm{C}(6)$ & $104.5(5)$ & 106.5 & $105.5(2)$ & 106.4 \\
\hline $\mathrm{C}(8)-\mathrm{N}(1)-\mathrm{Cu}$ & $123.6(4)$ & 120.6 & $120.8(2)$ & 120.6 \\
\hline $\mathrm{C}(6)-\mathrm{N}(1)-\mathrm{Cu}$ & $131.4(4)$ & 130.4 & $132.4(2)$ & 131.1 \\
\hline
\end{tabular}




\section{Figure captions}

Fig. 1 Molecular structure of msbi in the crystal (C10-Se 1.960(4) $\AA$, Se-C11 1.934(5) $\AA$, C10-Se-C11 97.1(2) $\left.{ }^{\circ}, \mathrm{C} 2-\mathrm{C} 10-\mathrm{Se}-\mathrm{C} 1166.0^{\circ}\right)$.

Fig. 2 Molecular structures of cation $\mathbf{1}^{+}$and solvated anion in the crystal of $[\mathbf{1}] \mathrm{Cl} \cdot 2 \mathrm{MeOH}$.

Fig. 3 Molecular structure of $2^{2+}$ in the crystal of $[2]\left(\mathrm{BF}_{4}\right)_{2}$.

Fig. 4 Coordination figures at the metal centers in the complex ions $\mathbf{1}^{+}$(left) and $\mathbf{2}^{\mathbf{2 +}}$ (right).

Fig. 5 Molecular structure of cation $3^{+}$in the crystal of $[3]\left(\mathrm{BF}_{4}\right)$.

Fig. 6 Molecular structure of averaged complexes in the crystal of [4][4']( $\left.\mathrm{PF}_{6}\right) \cdot \mathrm{CH}_{3} \mathrm{CN}$.

Fig. 7 Packing in the unit cell of single crystalline $[4]\left[4^{\prime}\right]\left(\mathrm{PF}_{6}\right) \cdot \mathrm{CH}_{3} \mathrm{CN}$.

Fig. 8 Coordination arrangement in $\left[\mathrm{Cu}(\mathrm{mpsbi})_{2}\right]^{+}$(top) and $\left[\mathrm{Cu}(\mathrm{mmb})_{2}\right]^{+}$(bottom). 
Figure 1

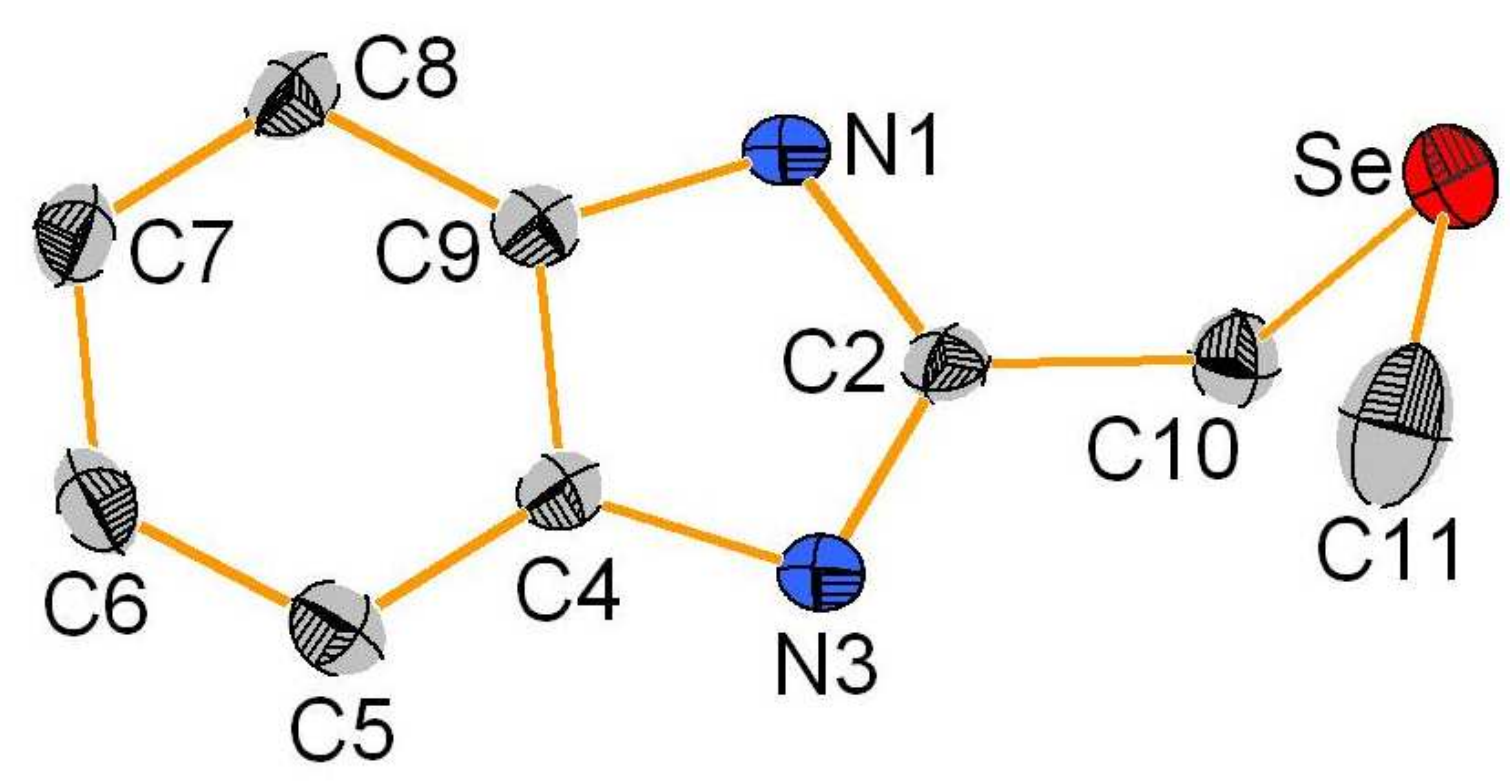


Figure 2
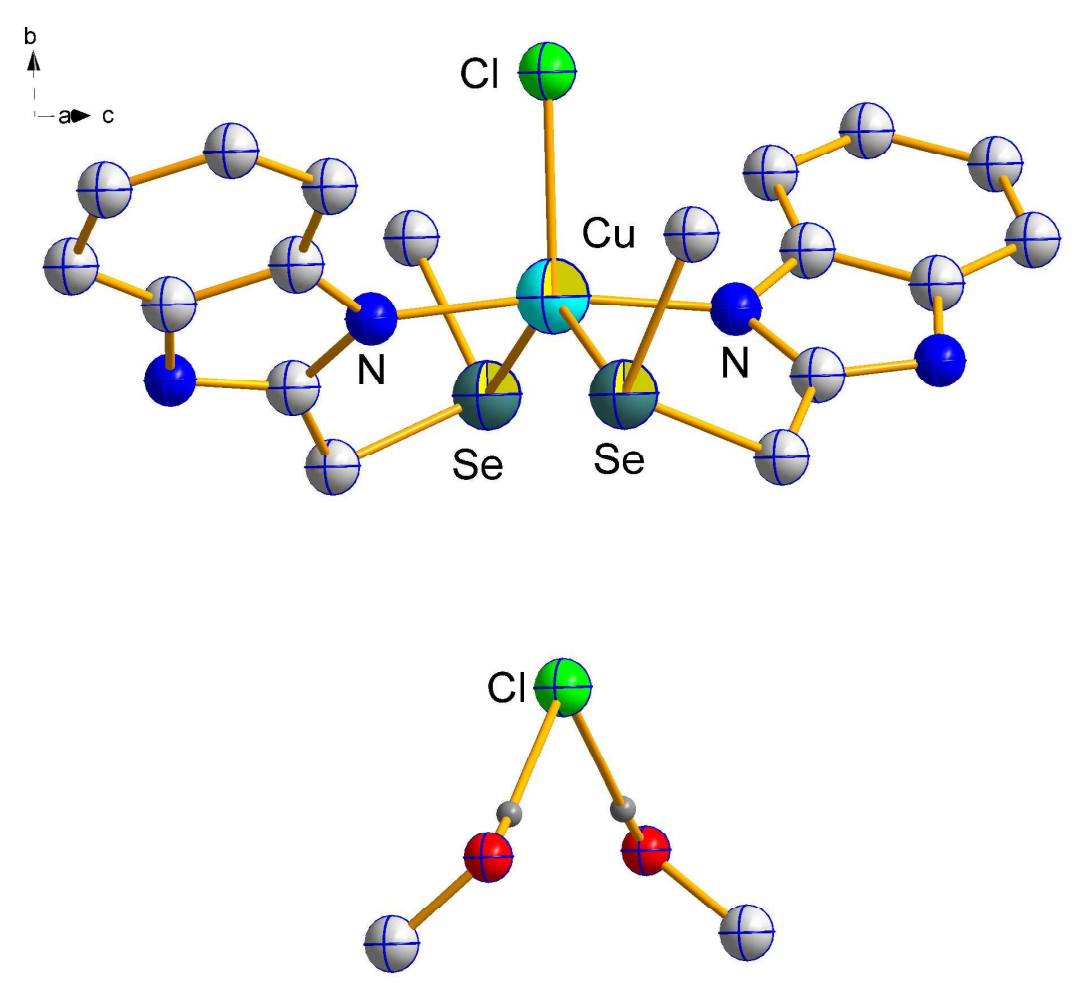

Wiley-VCH 
Figure 3

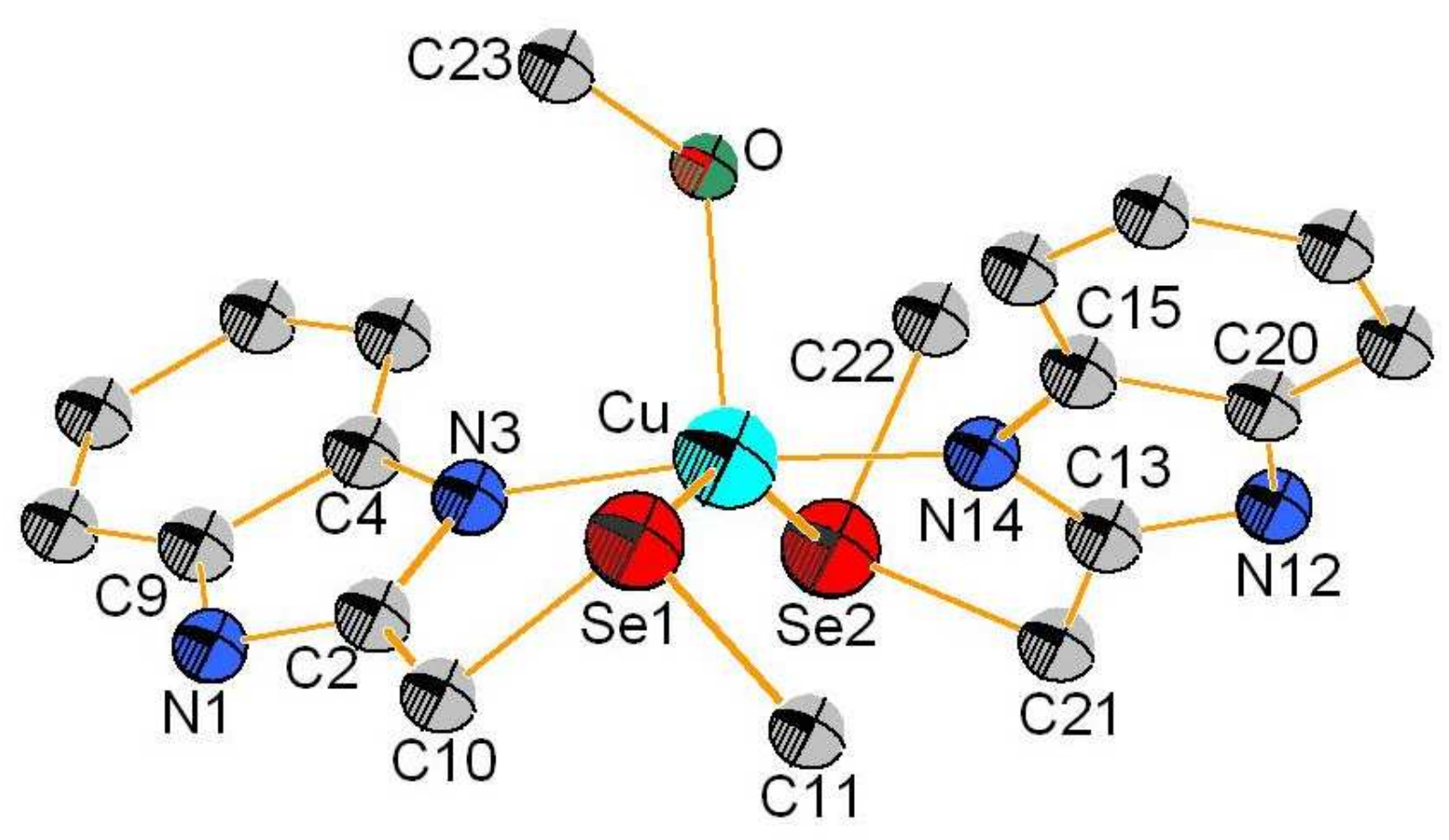


Figure 4
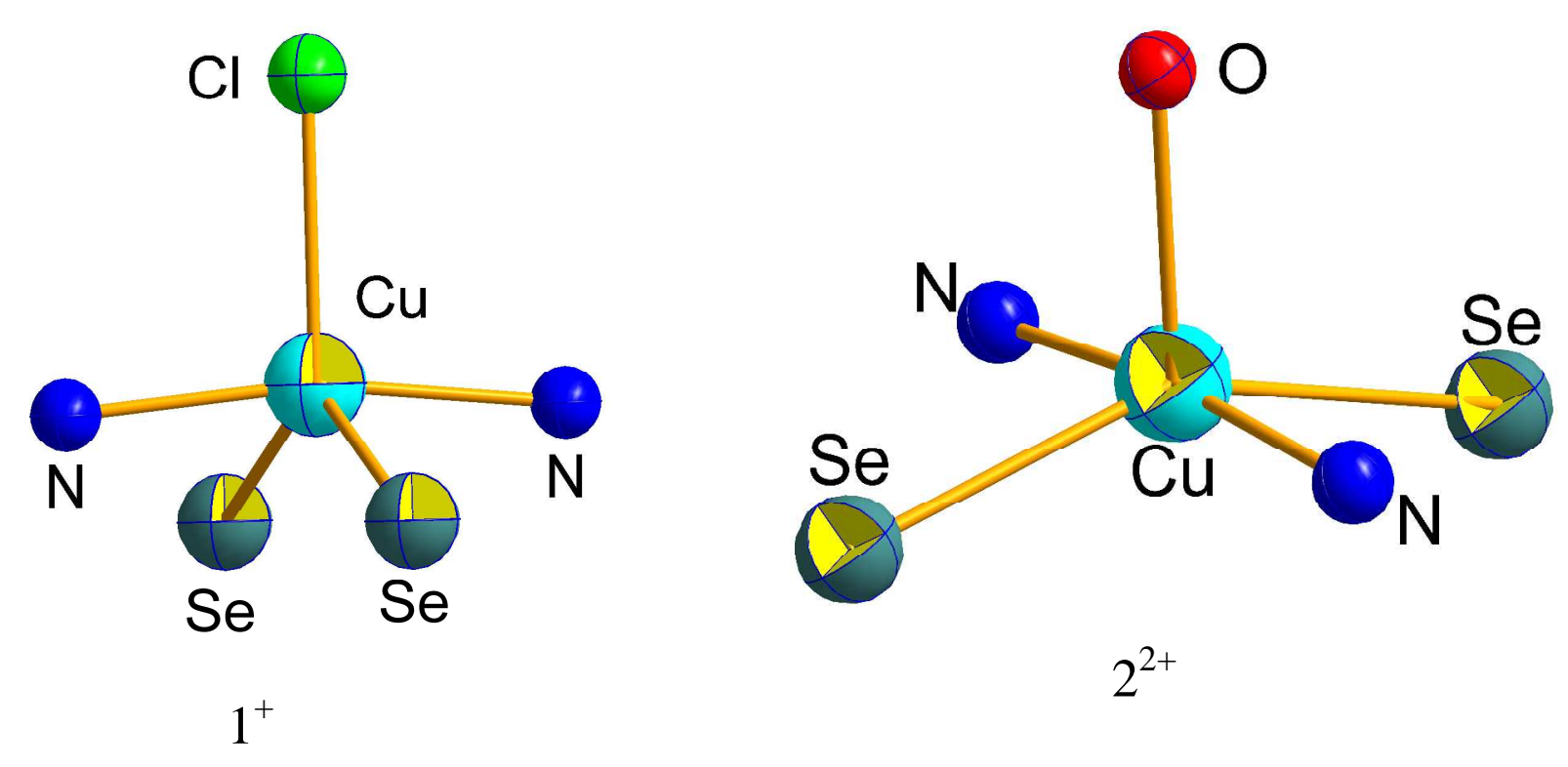
Figure 5

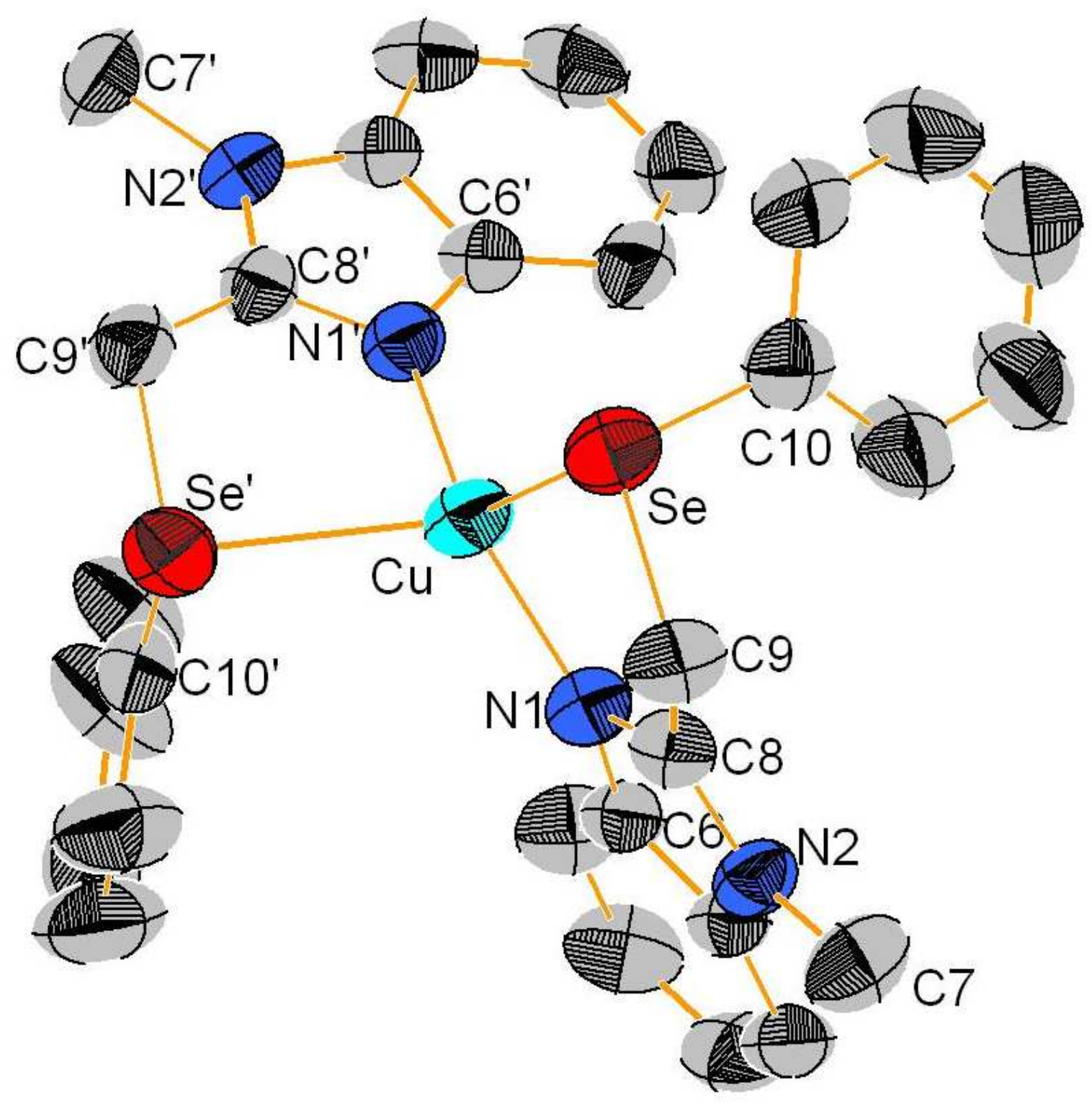




\section{Figure 6}
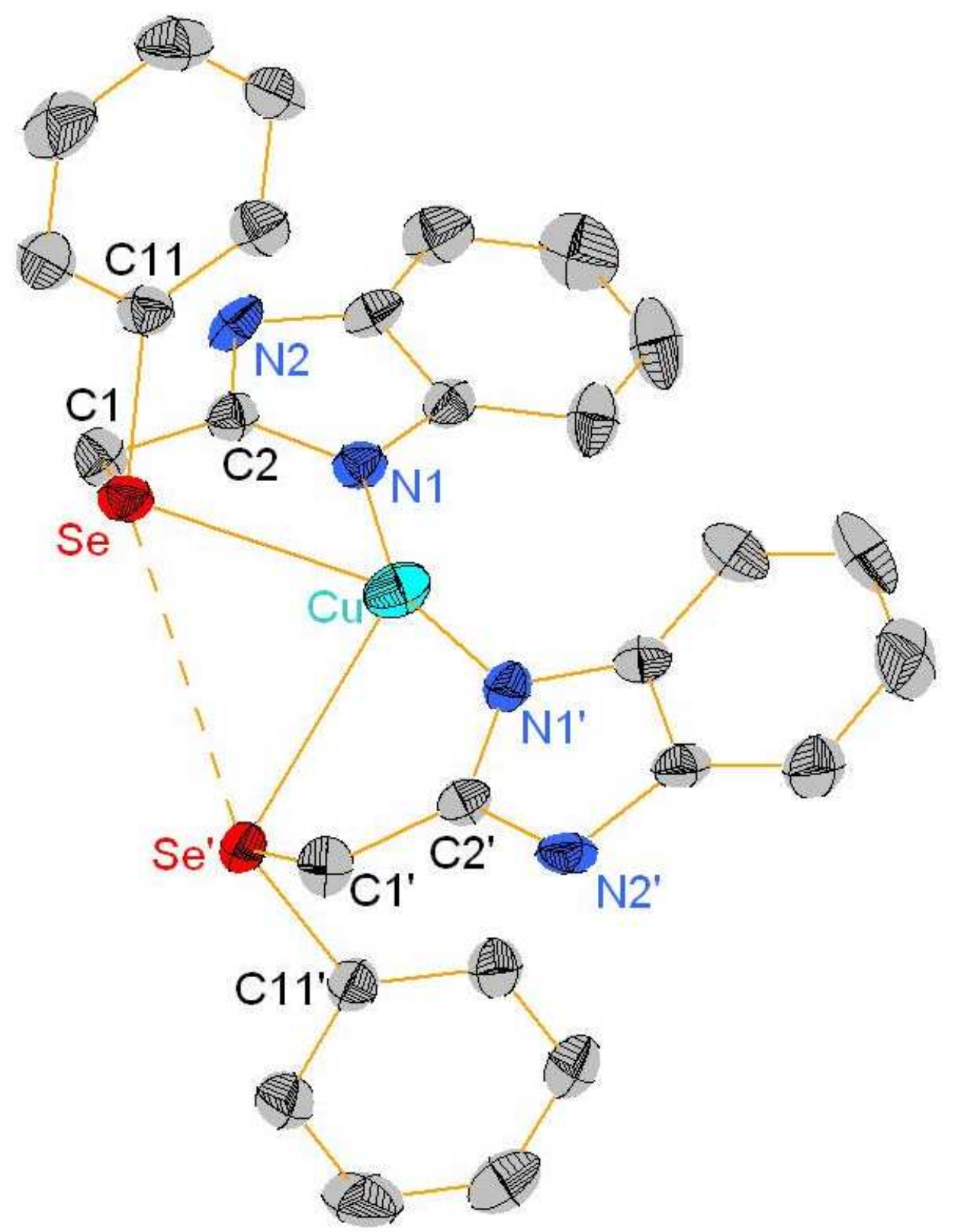
Figure 7

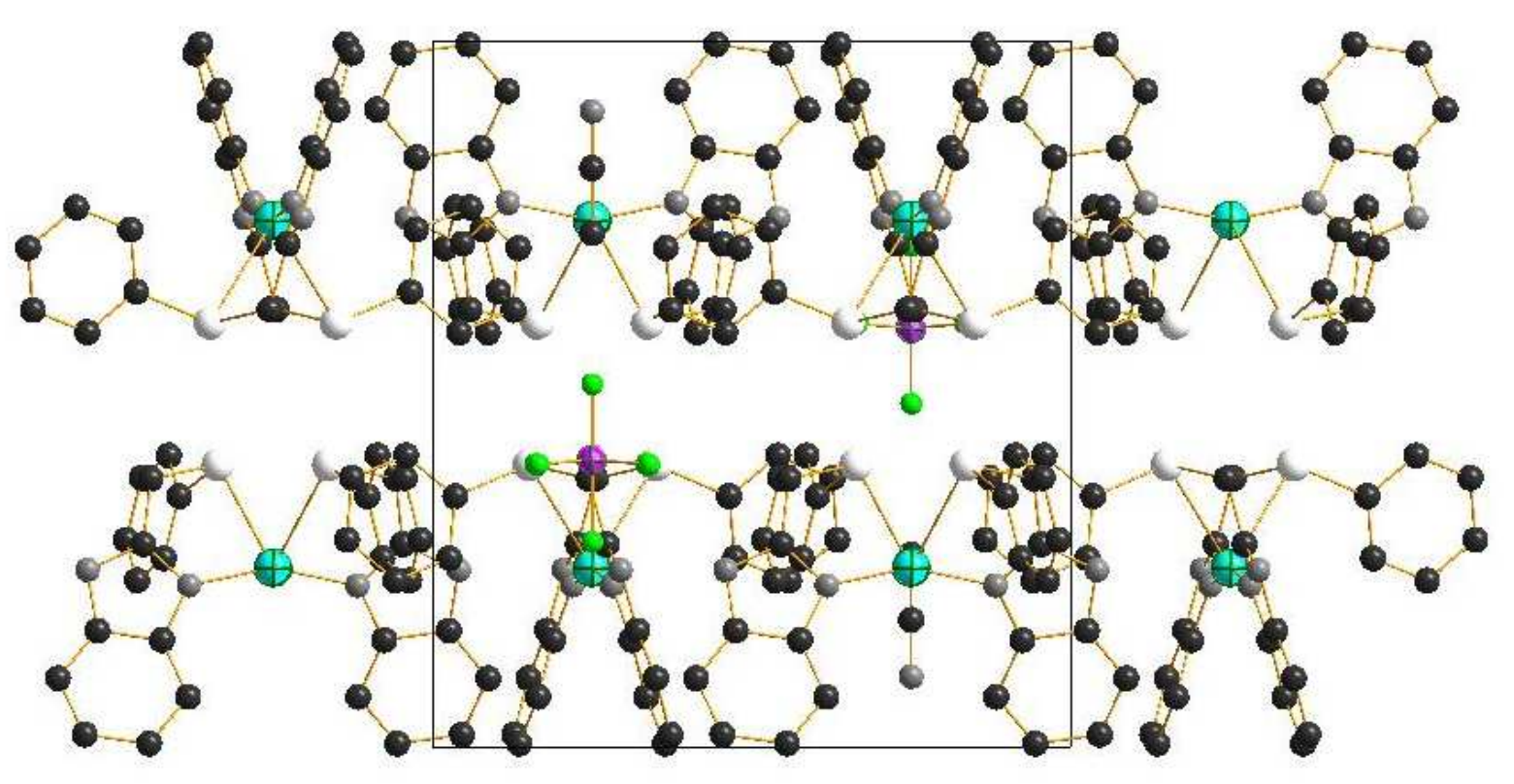




\section{Figure 8}

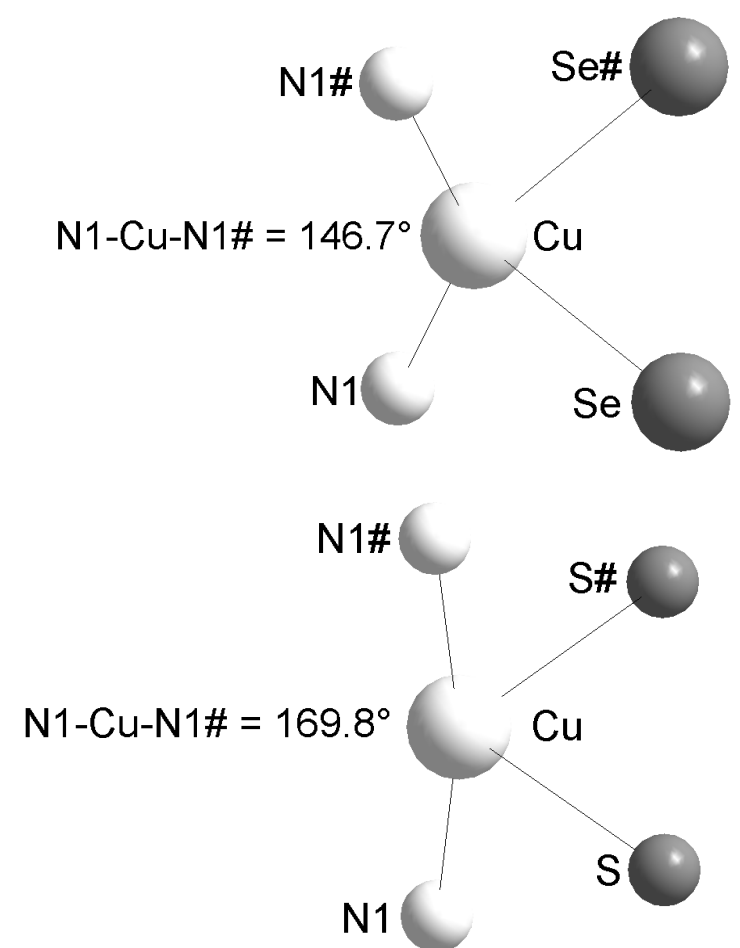

